\title{
Selected Determinants of the Attitudes of Educational Staff Towards Inclusive Education
}

\section{Kadra pedagogiczna wobec edukacji inkluzyjnej - wybrane determinanty postaw}

\section{KEYWORDS \\ inclusion, common education, attitudes, disability, determinants of attitudes}

\section{ABSTRACT}

The article brings up extremely important issues for disabled people: selected conditions for the success of the educational inclusion process. The research was conducted in a positivist paradigm and was focused on the attitudes of teachers and determinants of these attitudes. For diagnostic purposes, the research tool "Scale for Testing Teachers' Attitudes Towards Inclusive Education” was used. A total of 363 teachers, school counselors, and school psychologists took part in the study. They represented levels of education from kindergarten to middle school (which is currently part of primary school in any case). Both special and mainstream schools were represented in the study. Variables such as age, type of institution, level of education, and position were taken into account. The results confirmed the hypotheses that some variables - type of institution, level of education, and position-significantly discriminate the results of the groups.

\section{SŁOWA KLUCZE ABSTRAKT}

inkluzja, edukacja wspólna, postawy, niepełnosprawność, determinanty postaw
Artykuł porusza niezwykle ważny dla osób niepełnosprawnych temat dotyczący wybranych uwarunkowań powodzenia procesu inkluzji edukacyjnej. W badaniach utrzymanych w paradygmacie pozytywistycznym skupiono się na postawach nauczycieli i determinantach 
tychże postaw. Dla celów diagnostycznych użyto narzędzia badawczego „Skali do badania postaw nauczycieli wobec edukacji włączającej”. W badaniach wzięło udział 363 nauczycieli, pedagogów i psychologów szkolnych, reprezentujących szczeble edukacji od przedszkola po włączone w struktury obecnej szkoły podstawowej gimnazja. Reprezentowano placówki zarówno specjalne, jak i ogólnodostępne. Pod uwagę wzięto takie zmienne, jak: wiek, typ placówki, poziom edukacji oraz zajmowane stanowisko. Wyniki badań pozwoliły na przyjęcie hipotez, iż zmienne: typ placówki, poziom edukacji oraz zajmowane stanowisko istotnie różnicują wyniki prób.

\section{Introduction}

"A fundamental principle of modern schools is that all children should learn together. It is the implementation of their constitutional right to education, care, and upbringing, without exposing the children to personality deprivation" (Czyż 2014: 150). Scientific research proves that mixed inclusive education is more conducive to the development of children, both non-disabled and disabled, in every sphere of life. Mutual support and help instills sensitivity and encourages progress in the social understanding of norm and pathology. Sharing a classroom together opens students to otherness and teaches them acceptance, tolerance, and solidarity (FirkowskaMankiewicz 2004).

The idea of educational inclusion grows out of the natural tendencies to equalize the developmental opportunities of all people in the world. Inclusion and segregation trends have been intertwined in the history of all societies. The currently debated idea of educational inclusion dates back to $19^{\text {th }}$-century America, but it was only the $20^{\text {th }}$ century and the migrations in European countries that laid the foundations for all educational systems in which a place had to be found for a diverse, multinational, and multicultural population (Osgood 2005). The intermingling of the children of migrant populations with the locals in schools not only facilitated naturalization, but most of all prevented the deepening of the intellectual stratification of society. Access to education also guaranteed countries' economic and social stability (Leicester 2000). The understanding of the concept of inclusion did not change as such, but by influencing social awareness more and more, it underwent a natural maturation. Today, when considering the idea of inclusion, whether on social, economic, or educational grounds, scholars forego language which conceptualizes it as an artificial creation; instead, they represent it as something that happens evolutionarily and arises from citizen's natural ambitions to pursue opportunities for development and from their rights to equality. 
"Inclusive education creates conditions for the success of children with disabilities, the socially maladjusted, neglected children, children of various backgrounds, race, culture, or religious affiliation. It is a path that leads to the transformation of educational systems" (Czyż 2014: 150), by removing physical and legal barriers, but more importantly, fighting against prejudice and negative social attitudes. It concentrates on the usefulness of each individual, which contributes to the augmentation and maintenance of social homeostasis (Zamkowska 2004).

In order for inclusive education to become a reality, the law regulating the functioning of the Polish educational system, which was amended in 2017, had to clearly indicate where a child with special educational needs should fulfill their school obligation, to what extent the educational environment should be adapted to the student's individual needs, and which entities should be responsible for providing adequate support. The regulation focuses on the inclusion of children with special needs in mainstream schools, forbids the teaching of children with a slight degree of mental retardation in special institutions or the organization of special classes for them in mainstream schools; it also bans the organization of such classes for children who are socially maladjusted or at risk of maladjustment. Inclusive education offers challenges as well as opportunities. It involves the elimination of architectural barriers, often requiring not only a total renovation of rooms, but a complete reconstruction of buildings in order to equip them with disability-friendly features and devices (from general use to specific aids), adapting all educational aids to the specific set-up of the school (providing textbooks, e.g., in signwriting or Braille, or which tailor their content to the intellectual capabilities of the subjects). Inclusion means taking into account multiculturalism, the diversity of communication systems in the process of teaching and upbringing, including alternative and supportive forms of resource exchange, etc. It principally means setting appropriate educational goals: individual goals which are different for each child. Inclusion is also a comprehensive preparation of the teaching staff, delivering knowledge, skills, and competences to educators, which also considers the changing perception of the idea itself. It is treating new situations in terms of challenges that unleash the powers of agency, develop, expand, and broaden competences, and not in terms of obstacles and limitations (Regulation of the Ministry of National Education of August 24, 2017).

Incorporating the idea of inclusion-whether defined broadly as social inclusion or narrowed down to only the school—entails many obstacles, but despite the many diagnosed irregularities, we can observe continuous, if very slow changes in the right direction: seeking to create a common world (Szumski 2006). 


\section{Reports from Selected Studies on the Determinants of Inclusion}

Human disability is one of the predictors of social exclusion. Children with more complex and more severe forms of disability, manifested mainly as cognitive impairment—including communication disorders (Gajdzica 2011)—are particularly vulnerable to repression during the educational process. Inclusive education focuses on breaking down divisions, on recognizing that diversity can make children grow as human beings, and above all respects the individual needs of students. It is based on the social model of perceiving disability, which stipulates that the causes of disability are social, economic, legal, and organizational barriers created by society. Society is responsible for reducing the effects of disability and integrating disabled people into social life. Thus, the unassailable determinant of the success of the idea of inclusion are social attitudes and, particularly in educational terms, the attitudes of peers and the teaching staff themselves (Sękowski 1994; Czyż 2017). However, the research warns that the attitudes of students are not only negative, but also tend to worsen with age (Dudek 2009). The attitude of teachers and educators, on the other hand, is often seemingly positive or indifferent (Czyż 2018), though there are reasons to hypothesize that the attitude towards the very idea of inclusion does not correlate with teachers' level of empathy (Barłóg 2018). Among the predictors of the attitudes of teachers and educators who are responsible for the process of teaching children and adolescents with specific educational needs are not only demographic variables such as gender, age, work experience, level of education, and the teacher's preparation (Barnes, Gaines 2015; 2017), but also social factors such as one's personal or indirect experience of disease and disability (Brandy, Woolfson 2008), or factors related to the child undergoing inclusive education (Hammond, Ingalls 2003). These issues were addressed in research done by Anna Czyż in 2015 on understanding the idea of inclusive education; Iwona Myśliwczyk also confronted a similar dilemma in 2016.

Inclusive education is often confused with integrated education, where the integration model is in fact based on segregation: the students undergo selection and they are matched to schools/groups, whereas in inclusive education the school is matched to the students' needs. Using these terms interchangeably, although it has been advocated by some, should not be done (Lechta 2010; Al-Khamisy 2013; Chrzanowska 2014). The names correlate closely with the teaching/learning models and do not represent the same thing. In order to understand those differences and the idea of inclusion, we must first foster a mindset of openness in ourselves and dispense with the rigid framework that pigeonholes people into imposed patterns of actions and standards of behavior, procedures, appearances, and skills. The Polish and foreign studies on the topic are often inconsistent and contradictory. However, assuming that inclusive 
education serves the development of subjects and seeks to abolish the divisions into the superior and the inferior, into others- the normal and not normal, the deserving and the undeserving - we should keep discovering the local and global circumstances that are favorable to its success.

\section{The Methodology of Research on the Determinants of Teachers' Attitudes Towards the Idea of Inclusive Education}

The aim of this research was to identify the determinants of teachers' attitudes towards inclusive education in Polish schools. Carried out according to the positivist paradigm (Creswell 2009), it was based on Blumer's theory of attitudes (1936) and the continuation of it by Zimbardo \& Leippe (2004), as well as on Oppenheim's guidelines for measuring attitudes (2004). The stimulus for conducting research on the relationship between teachers' attitudes and the success of the concept of inclusion was the studies by Rakap and Kaczmarek (2010), Ross-Hill (2009), and Ringlaben and Griffith (2008), which confirmed that the positive attitude of people from educational communities, including teachers and educators, is the main determinant of the success of inclusive education. The study included a sample of 363 teachers, counselors, and psychologists from public education institutions (Table 1). The "Scale for Testing Attitudes Towards Inclusive Education" was the tool used to determine the direction of the attitude. The tool was constructed for the purposes of this study, based on a 5-point Likert scale which measures the respondents' feelings and opinions about an issue on a scale from "strongly agree" to "strongly disagree." It is a complex measure, where each estimated item contains cognitive, emotional, and behavioral components. The tool was pre-standardized. Cronbach's alpha was calculated at 0.85 . Reverse scoring was used for 20 questions. The mean number of points (M) for each question was used for weighting and was included in the analyses of intergroup differences and in the construction of the interpretation key for assessing the direction and intensity of attitudes in the first stage of the analysis. The final version of the tool includes 43 out of 48 items; the remaining items were eliminated based on power analysis using the approximation method.

The substantive basis for the construction of the tool was derived from the guidelines of the European Agency for Development in Special Needs Education, created with the support of the General Directorate for Education and Culture of the European Commission. In addition, I followed the guidelines contained from the laws and regulations of the Minister of National Education regarding the organization 
of the educational system and the preparation of teachers to work in the profession in Poland (Regulation of the Ministry of National Education of August 24, 2017).

Table 1. Characteristics of the Study Sample

\begin{tabular}{|c|c|}
\hline Variables, after the random reduction of cases & Number \\
\hline Total sample & 363 \\
\hline \multicolumn{2}{|l|}{ Age (years) } \\
\hline $25-30$ & 51 \\
\hline $31-35$ & 64 \\
\hline $36-40$ & 64 \\
\hline $41-45$ & 65 \\
\hline$\geq 46$ & 64 \\
\hline \multicolumn{2}{|l|}{ Type of school } \\
\hline Special & 127 \\
\hline Mainstream & 129 \\
\hline \multicolumn{2}{|l|}{ Level of education taught } \\
\hline Kindergarten & 52 \\
\hline Primary school & 52 \\
\hline Middle school & 47 \\
\hline \multicolumn{2}{|l|}{ Job title } \\
\hline Teacher & 49 \\
\hline School counselor & 49 \\
\hline School psychologist & 49 \\
\hline
\end{tabular}

In the first stage of research, I determined the direction and intensity of the attitudes towards inclusion in Polish schools and analyzed the results in terms of the relationship with the first variable: the type of school. The findings from my 2018 study show that the vast majority of respondents exhibit a neutral attitude, yet a trend can be observed for mainstream teachers to present more positive attitudes towards inclusive education (Czyż 2018). Therefore, it was important to carry out another study to identify the determinants of these attitudes. The following variables were measured: the age of respondents, the type and level of the school where they taught, 
and their job title. The research was exploratory and quantitative. Parametric statistics were used to evaluate the relationships: one-way analysis of variance (ANOVA) and Student's t-test for two independent variables. Tukey's HSD test was employed in the post hoc analysis to find means that were significantly different from each other. In order to draw comparisons, software for random reductions of cases was used to equalize the size of the subgroups. The normality of the probability distribution was tested using the Lilliefors-corrected Kolmogorov-Smirnov test (K-S-D test), and the homogeneity of variance was measured using Levene's test. The research sample met all the requirements for conducting parametric statistics. The following thresholds of statistical significance were adopted for the statistical analysis: ${ }^{*} p \leq 0.05$ - sufficient statistical significance, ${ }^{* *} p \leq 0.01$ - high statistical significance, and ${ }^{* * *} p \leq 0.001-$ very high statistical significance. Taking into account the requirements for the selected parametric tests, the following hypotheses (main and alternative) were made:

HO: $\mathrm{F} 1=\mathrm{F} 2-$ The samples come from one population.

H1: $\mathrm{F} 1 \neq \mathrm{F} 2-$ The samples come from different populations.

The statistical data were analyzed with Statistica v. 13.1 software.

\section{Results}

The relationship between the respondents' ages and their attitudes towards inclusive education was first verified (Table 2, Figure 1). ANOVA revealed a statistically significant difference between the attitude and the age variable at the level of $p=0.05$. However, after applying Tukey's test for post hoc analyses, no statistically significant differences between the groups were found. Hypothesis $H 1$, which states that the age variable differentiates the respondent groups, was therefore rejected, but the main hypothesis- $\mathrm{HO}$, that there is no correlation between the age variable and the direction of the attitude - was not proven either. Further research should be conducted to shed light on other variables that moderate this possible relationship. 
Figure 1. ANOVA test results (age and attitude)

$$
\text { Age }
$$

Current effect $F(4,296)=2.3969, p=0.05042$

Vertical bars represent $95 \%$ confidence intervals

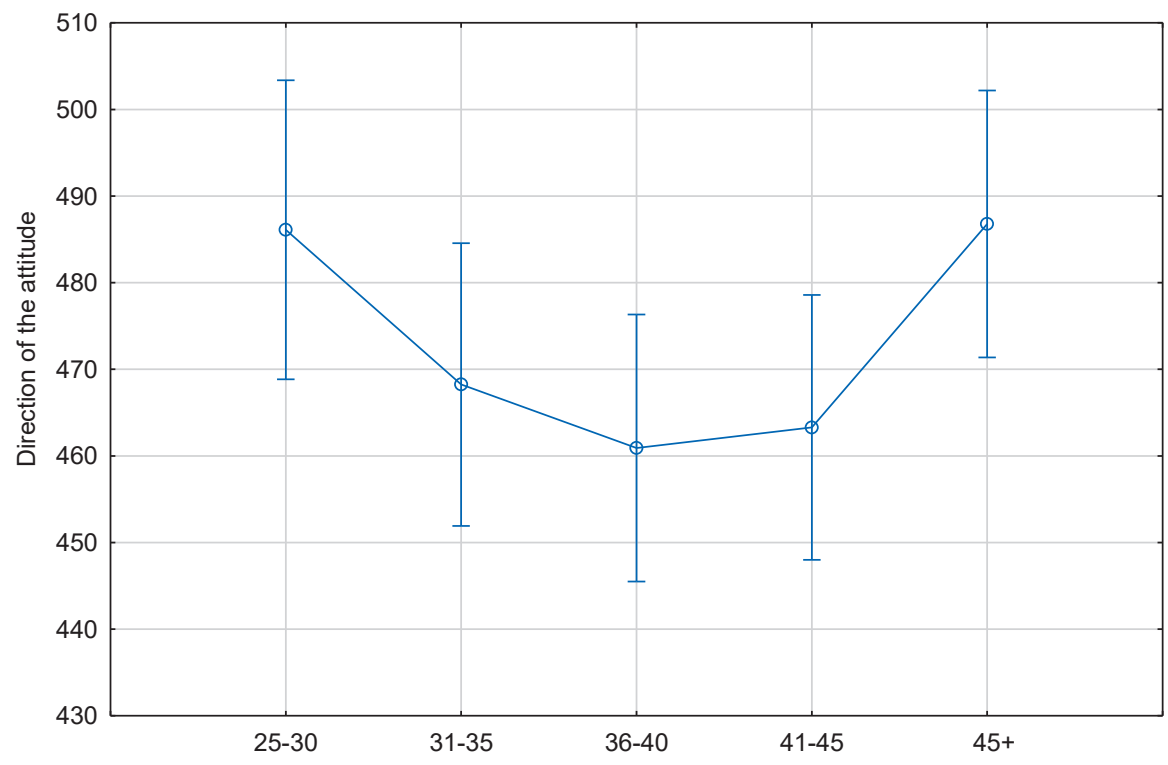

Table 2. Results of Tukey's HSD test for different N (age and attitude)

\begin{tabular}{|c|c|c|c|c|c|}
\hline Age & $\begin{array}{c}\{1\} \\
486.11\end{array}$ & $\begin{array}{c}\{2\} \\
468.24\end{array}$ & $\begin{array}{c}\{3\} \\
460.91\end{array}$ & $\begin{array}{c}\{4\} \\
463.29\end{array}$ & $\begin{array}{c}\{5\} \\
486.77\end{array}$ \\
\hline $25-30$ & & 0.602 & 0.251 & 0.351 & 1.000 \\
\hline $31-35$ & 0.602 & & 0.971 & 0.993 & 0.511 \\
\hline $36-40$ & 0.251 & 0.971 & & 1.000 & 0.134 \\
\hline $41-45$ & 0.351 & 0.993 & 1.000 & & 0.211 \\
\hline over 45 & 1.000 & 0.511 & 0.134 & 0.211 & \\
\hline
\end{tabular}


Another variable examined in the study was the type of school the respondents worked at. Student's t-test for two independent variables was used for the analysis. The results demonstrate a highly statistically significant relationship between the variables studied. Taking into account the result of the t-test and the group means, it can be concluded that representatives of special schools hold a significantly more negative attitude towards the idea of inclusive education than representatives of mainstream schools (Table 3, Figure 2). On the basis of the statistical calculations, an alternative Hypothesis $H 1$ was adopted: The type of school significantly differentiates the results of the samples.

Figure 2. Results of Student's t-test for two independent variables (type of school and attitude)

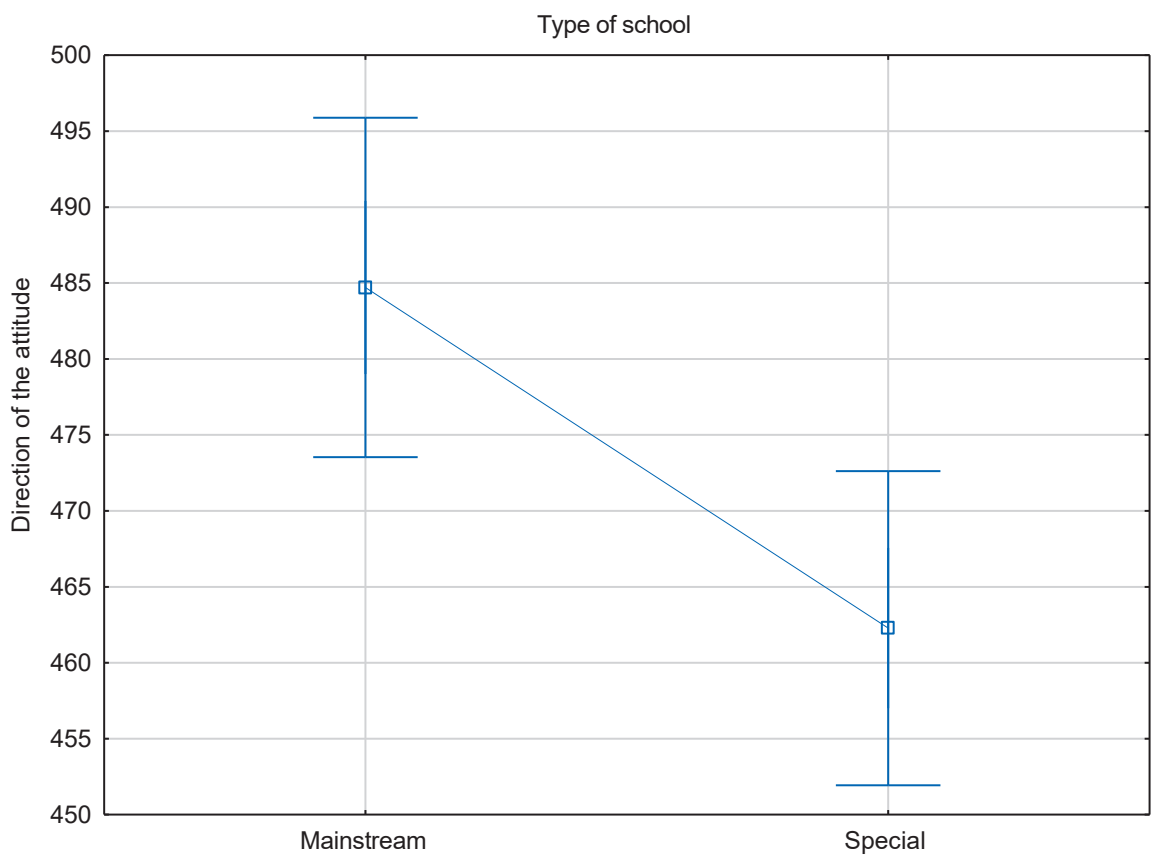


Table 3. Results of Student's t-test for two independent variables (type of school and attitude)

\begin{tabular}{|c|c|c|c|c|c|c|c|c|}
\hline \multicolumn{2}{|c|}{ t-test; variable: type of school } \\
\hline $\begin{array}{c}M . \\
\text { mainstream }\end{array}$ & $\begin{array}{c}M . \\
\text { special }\end{array}$ & $\mathrm{t}$ & $\mathrm{df}$ & $p$ & $\begin{array}{c}\text { SD } \\
\text { Mainstream }\end{array}$ & $\begin{array}{c}\text { SD } \\
\text { Special }\end{array}$ & $\begin{array}{c}\text { F statistic } \\
\text { Variances }\end{array}$ & $\begin{array}{c}p \\
\text { Variances }\end{array}$ \\
\hline 484.71 & 462.28 & 2.89 & 254 & $0.004^{* *}$ & 64.73 & 59.45 & 1.19 & 0.34 \\
\hline
\end{tabular}

Another relationship that was tested is the level of education and the direction of attitude. Only teachers were included in the study groups. The previous organizational structure (before 2016), with schools divided into primary school and middle school, was kept in order to separate these two levels of education (in the current system, middle schools have been disbanded and grades 7 and 8 are part of primary school, while the last year of middle school is now part of high school). The sample of primary school teachers included the teachers of today's grades $1-6$. The findings demonstrated a highly significant correlation between the variables for education level and direction of attitude (ANOVA; Figure 3), while post hoc analysis using Tukey's test revealed a statistically significant relationship between the results of the sample of kindergarten teachers and primary school teachers. The Tukey's HSD test results and the means (Table 4, Figure 3) show that primary school teachers express a significantly more negative attitude towards inclusion than preschool teachers. Moreover, a second statistically significant relationship was revealed. Primary school teachers exhibit significantly more negative attitudes than middle school teachers. Consideration of these results (ANOVA and Tukey's HSD test) led us to build an alternative Hypothesis H1: The variable for level of education significantly differentiates the results of the samples. 
Figure 3. ANOVA test results (education level and attitude)

Level of education

Current effect $F(2,148)=5.7867, p=0.00380$

Vertical bars represent $95 \%$ confidence intervals

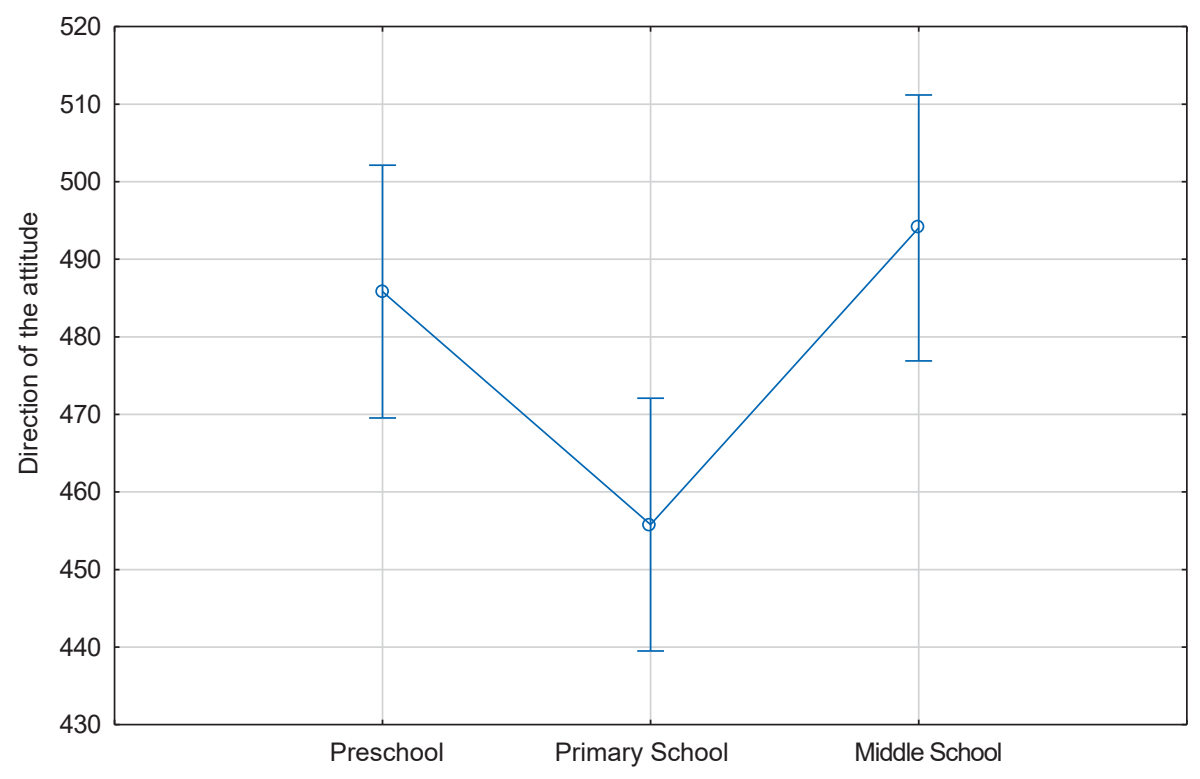

Table 4. Tukey's HSD test results (education level and attitude)

HSD test; approximate probabilities for post hoc tests; Error: intergroup MS = 3538.3, $\mathrm{df}=148.00$

\begin{tabular}{|c|c|c|c|}
\hline Level of education taught & $\begin{array}{c}\{1\} \\
485.84\end{array}$ & $\begin{array}{c}\{2\} \\
455.79\end{array}$ & $\begin{array}{c}\{3\} \\
494.05\end{array}$ \\
\hline Kindergarten & & $0.027^{*}$ & 0.772 \\
\hline Primary school & $0.027^{*}$ & & $0.004^{* *}$ \\
\hline Middle school & 0.772 & $0.004^{* *}$ & \\
\hline
\end{tabular}

The final variable studied was the respondents' job title. The data came from teachers, counselors, and psychologists. A very strong correlation was revealed between the job position variable and the direction of the attitude (Figure 4). Post hoc analysis with the Tukey's HSD test (Table 5) showed two intergroup differences. After computing the mean values and the statistical significance of the relationships, we can conclude 
that there is a sufficiently strong relationship between the variants teachers and psychologists (teachers show more positive attitudes towards the idea of inclusion than psychologists) and a very strong statistical relationship—a statistically significant difference- - between the variants counselors and psychologists (counselors display much more positive attitudes towards the idea of inclusion than psychologists). Based on the above results (ANOVA and Tukey's HSD test), I constructed an alternative Hypothesis H1: The job position variable significantly differentiates the results of the samples.

Figure 4. ANOVA test results (job position and attitude)

\section{Job title}

Current effect $F(2,148)=9.8004, p=0.00010$

Vertical bars represent $95 \%$ confidence intervals

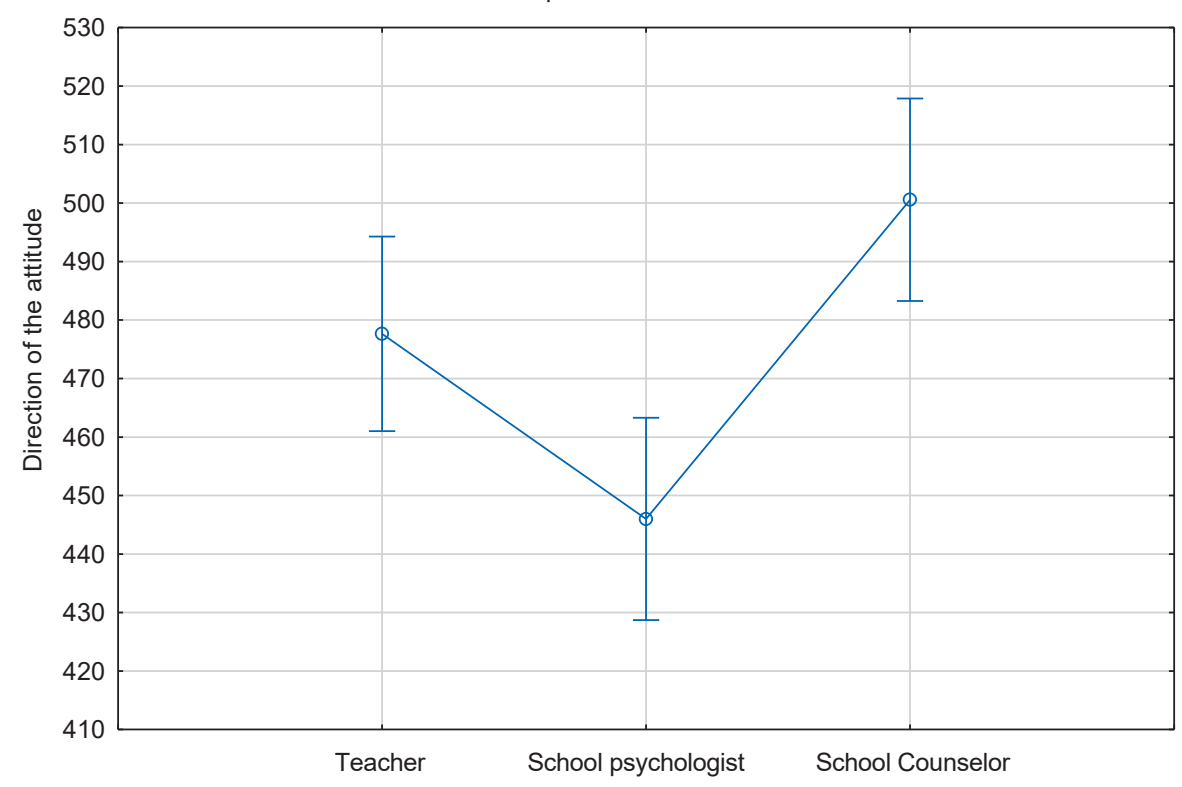

Table 5. Tukey's HSD test results (job position and attitude)

HSD test; approximate probabilities for post hoc tests; Error: intergroup MS = 3754.3, $\mathrm{df}=148.00$

\begin{tabular}{|c|c|c|c|}
\hline Job title & $\{1\} 477.64$ & $\{2\} 446.01$ & $\{3\} 500.57$ \\
\hline Teacher & & $0.025^{*}$ & 0.142 \\
\hline School psychologist & $0.025^{*}$ & & $0.000^{* * *}$ \\
\hline School counselor & 0.142 & $0.000^{* * *}$ & \\
\hline
\end{tabular}




\section{Summary of Findings}

- The research results led me to formulate the hypotheses that the type of school, level of education, and job title significantly differentiate the groups of teachers and educators.

- In the case of the age variable, despite the statistical significance of the correlation, we cannot accept the hypothesis that the variable is discriminant. No intergroup difference was detected in the post hoc analysis.

- The respondents from mainstream schools held a significantly more positive attitude towards inclusion than the respondents from special schools.

- Primary school teachers displayed a significantly more negative attitude than the teachers from kindergartens and middle schools.

- Finally, the attitudes of psychologists were found to be significantly more negative than those of teachers and counselors.

\section{Discussion}

This study examined selected determinants of attitudes of teachers: adults closest to the children in the educational setting and responsible for their behavior, the quality of education and teaching, and their wellbeing in the peer group. Bearing in mind the analyses carried out at the end of 2018, which found that the vast majority of the surveyed teachers/educators exhibited neutral attitudes towards inclusive education, I have searched for the factors that may contribute to more positive or more negative attitudes. Four variables were analyzed: age, the type of school, the level of education taught, and the job title of the respondents. For three of them (type of school, level of education, and job title), a hypothesis was formulated stating that the variables significantly differentiate the results; in the case of one, i.e., the age of the respondents, it is recommended that further research be conducted in order to find an additional factor that, when combined with the age variable age, will prove to be discriminant.

Taking into account the results of the variable for level of school taught, future studies should investigate whether the sample with the lowest results, i.e., primary school teachers (grades 1-6) present different results after being further divided into subgroups: teachers representing grades 1-3 (early school education) and teachers of grades 4-6 (teaching of separate subjects). It is conjectured that factors which contribute to negative attitudes may be the child's transition from early childhood education to subject-based education, the increasing level of educational requirements, and the departure from education focused on the development of basic competences towards the child's acquisition of specialized subject knowledge. Bearing in mind also 
that kindergarten teachers express the most positive attitudes among all respondents, we can presume that the pupils' age may correlate with this attitude. The more negative attitudes of the middle school teachers can be explained (unfortunately) by the selection of students who become admitted to lower secondary schools. In view of this interpretation, the findings may prove that educational institutions are not prepared to implement inclusive education.

The most surprising results came from the variable for type of school—special or mainstream. The respondents from special schools demonstrated a more negative attitude than those from mainstream schools. It cannot be ascertained whether such attitudes are related to the approach "for the good of the child" (the teachers do not want to risk the children feeling different, being ridiculed and bullied, confronting an inadequate teaching system, etc.) or to the teachers being stuck in a rigid system with deep-rooted traditions of segregation, or perhaps to the subjectivity of the teachers themselves, their personality, or their purposeful actions to fulfill needs such as maintaining their professional position or their independence in that position. In future research, it is also worth comparing the self-assessment of the competences of special education professionals with that of teachers and counselors of mainstream schools. One supposition is that a high assessment of one's own preparation for this profession combined with a low assessment of the competences of colleagues from public schools may foster negative attitudes towards the idea of inclusion.

Lastly, the findings reveal that, with reference to the job position, school psychologists show the least positive attitude among all respondents. The fact is that of all members of the pedagogical body, they have the least interaction with children, and most of this contact is devoted to diagnosis. They are also not responsible - strictly and on a daily basis_-for teaching and raising children. However, given that they are very important actors in implementing the idea of inclusion, it is worth taking a closer look at the determinants of attitudes in this study group.

\section{Conclusion}

This study explores only a fraction of the educational reality. It draws attention to the need to conduct research on larger samples and to include many replacement variables. Only a few relationships were discovered and three determinants of attitudes towards the idea of inclusion in the teaching community are presented. What surprised me as a researcher was, first of all, that special school teachers express more negative attitudes towards the idea of inclusion than mainstream school teachers, and that the attitudes of psychologists are more negative than those of teachers and educators. In the discussion, I attempt to explain the reasons for this state of affairs and 
highlight the need for further research and analysis. As the results have shown, what seems obvious and true is not always the case in reality.

\section{Bibliography}

Al-Khamisy D. (2013). Edukacja wtaczajaca edukacja dialogu. W poszukiwaniu modelu edukacji dla ucznia ze specjalnymi potrzebami edukacyjnymi [Inclusive education as an education of dialogue: In search of an educational model for a student with special educational needs], Warsaw: Academy of Special Needs Pedagogy.

Barłóg K. (2018). Edukacja i zmiana - nastawienia empatyczne nauczycieli i uczniów w edukacji inkluzyjnej [Education and change: Empathetic attitudes of teachers and students in inclusive education], "Edukacja - Technika - Informatyka," no. 1/23, pp. 211-217.

Barnes M.C., Gaines T. (2015). Teachers' attitudes and perceptions of inclusion in relation to grade level and years of experience, "Electronic Journal for Inclusive Education," no. 3, 3, item 3 .

Barnes M.C., Gaines T. (2017). Perceptions and attitudes about inclusion: Findings across all grade levels and years of teaching experience, "Cogent Education," vol. 4/1. DOI: 10.1080/2331186X.2017.1313561.

Blumer H. (1936). Social attitudes and nonsymbolic interaction, "Journal of Educational Sociology," vol. 9, pp. 515-523.

Brady K. \& Woolfson L. (2008). What teacher factors influence their attributions for children's difficulties in learning? "British Journal of Educational Psychology," no. 78, pp. 527-544. DOI: 10.1348/000709907X268570.

Chrzanowska I. (2014). Nauczanie inkluzyjne w doświadczeniach polskich - podstawy prawne $i$ spoteczne uwarunkowania, [Inclusive teaching in the Polish experience: Legal and social conditions], "Studia Edukacyjne," no. 30, pp. 109-117.

Czyż A. (2013). Idea edukacji wtaczającej w opinii pedagogów [The idea of inclusive education in the opinion of educators], [in:] B. Grochmal-Bach, A. Czyż, A. Skoczek (eds.), Segregacja - integracja - inkluzja [Segregation - integration - inclusion], Krakow: Jesuit University Ignatianum in Krakow; WAM, pp. 35-57.

Czyż A. (2014). Od segregacji po inkluzje - refleksje [From segregation to inclusion: Reflections], [in:] S. Kurzeja, M. Penczka (eds.), W drodze ku dorostości - wyzwania i szanse dla procesu edukacji i rehabilitacji osób z niepetnosprawnościa [On the way to adulthood: The challenges and opportunities for the process of education and rehabilitation of people with disabilities], Katowice: Gnome, pp. 142-159.

Czyż A. (2015). Inkluzja edukacyjna osób z uszkodzonym narzadem stuchu - potrzeby i rzeczywistosíc [Educational inclusion of people with hearing impairment: Needs and reality], [in:] I. Ocetkiewicz, J. Wnęk-Gozdek, N. Wrzeszcz (eds.), Szkota: wspótczesne konteksty interpretacyjne [School: contemporary interpretive contexts], Krakow: University of Pedagogy Press, pp. 144-158.

Czyż A. (2017). Miejsce osób tożsamościowo Gtuchych w modelu otwartej edukacji XXI wie$k u$ [The place of Deaf people in the open educational model of the 21st century], 
"Elementary Education in Theory and Practice," vol. 12, no. 2, pp. 13-24. DOI: 10.14632/eetp.2017.12.44.13.

Czyż A. (2018). An analysis of Polish teachers attitudes towards inclusive education, "Future Human Image,” vol. 10, pp. 4-19.

Dudek M. (2009). Postawy mtodzieży gimnazjalnej wobec osób niepetnosprawnych [Attitudes of middle school students towards disabled people], [in:] M. Dycht, L. Marszałek (eds.), Inkluzja i ekskluzja spoteczna osób z niepetna sprawnościa [Social inclusion and exclusion of people with disabilities], Warsaw: Salezjańskie, pp. 133-145.

Firkowska-Mankiewicz A. (2004). Edukacja wtaczająca - wyzwaniem dla polskiej szkoty [Inclusive education: A challenge for Polish schools], "Szkoła Specjalna," no. 1, pp. 19-26.

Gajdzica Z. (2011). Opinie nauczycieli szkót ogólnodostępnych na temat edukacji wtaczającej uczniów z lekkim upośledzeniem umystowym w kontekście toczącej się reformy ksztatcenia specjalnego [Mainstream teachers' views on inclusive education for students with mild mental retardation in the context of the ongoing reform of special education], [in:] Z. Gajdzica (ed.), Uczeń z niepetnosprawnością w szkole ogólnodostępnej [Students with disabilities in mainstream school], Sosnowiec: Humanitas WSH, pp. 56-79.

Hammond H., Ingalls L. (2003). Teachers' attitudes toward inclusion: Survey results from elementary school teachers in three southwestern rural school districts, "Rural Special Education Quarterly," no. 22(2), pp. 24-30.

Lechta V. (2010). Pedagogika inkluzyjna [Inclusive pedagogy], [in:] B. Śliwerski (ed.), Pedagogika. Subdyscypliny $i$ dziedziny wiedzy o edukacji [Education: Subdisciplines and areas of knowledge about education], vol. 4, Gdańsk: Gdańsk Pedagogical Press, pp. 324-326.

Leicester M. (2000). Integrowanie nierówności [Integrating inequalities], [in:] G. Fairbairn, S. Fairbairn (eds.), Integracja dzieci o specjalnych potrzebach. Wybrane zagadnienia etyczne [Integration of children with special needs: Selected ethical issues], Warsaw: Publisher of the Center of Psychological and Pedagogical Assistance, pp. 123-141.

Myśliwczyk I. (2016). Inkluzja edukacyjna na etapie przedszkola w rozumieniu rodziców dzieci niepetnosprawnych [Educational inclusion at the preschool stage as understood by parents of disabled children], "Problemy Wczesnej Edukacji," no. 2/33, pp. 166180. DOI:10.5604/01.3001.0009.4833.

Oppenheim A. (2004). Kwestionariusze, Wywiady, Pomiary Postaw [Questionnaires, interviews, and attitude measurements], Poznań: Zysk i S-ka.

Osgood R.L. (2005). The history of inclusion in the United States. Washington, DC: Gallaudet University Press.

Rakap S., Kaczmarek L. (2010). Teachers' attitudes towards inclusion in Turkey, "European Journal of Special Needs Education," 25, 1, pp. 59-75. DOI: $10.1080 / 08856250903450848$.

Ringlaben R.P., Griffith K. (2008). The impact of attitudes on individuals with developmental disabilities, [in:] H.P. Parette, G. Peterson-Karlan (eds.), Research-based practices in developmental disabilities, Austin, TX: ProEd., pp. 453-477. 
Ross-Hill R. (2009). Teacher attitudes towards inclusion practices and special needs students, "Journal of Research in Special Education Needs," 9, 3, pp. 188-198. DOI:10.1111/j.1471-3802.2009.01135.x.

Sękowski A. (1994). Psychospoteczne determinanty postaw wobec inwalidów [Psychosocial determinants of attitudes towards the disabled], Lublin: UMCS.

Szumski G. (2006). Integracyjne ksztatcenie niepetnosprawnych. Sens i granice zmiany edukacyjnej [Integrative education for the disabled: The meaning and limits of education reform], Warsaw: PWN Scientific Publishing House.

Zamkowska A. (2004). Systemy ksztatcenia integracyjnego w wybranych krajach Unii Europejskiej [Integrative educational systems in selected European Union countries], Radom: Radom University of Technology.

Zimbardo P., Leippe M. (2004). Psychologia zmiany postaw i wptywu spotecznego [Psychology of changing attitudes and social impact], Poznań: Zysk i S-ka.

\section{Legal acts}

Act of December 14, 2016 - Education Law (Journal Of Laws of 2017, items 59 and 949).

Regulation of the Ministry of National Education of August 24, 2017, on the Organization of Conditions for the Education, Upbringing, and Care of Disabled Children and Adolescents, as well as Those Socially Maladjusted and At Risk of Social Maladjustment, pursuant to Art. 127 para. 19 point 2 of the Act of December 14, 2016 Education Law.

ADDRESS FOR CORRESPONDENCE

Anna Katarzyna Czyż

Pedagogical University of Krakow e-mail: anna.czyz@up.krakow.pl 